\title{
OSOBA W UJECIU GABRIELA MARCELA JAKO ŹRÓDŁO INSPIRACJI WYCHOWAWCZYCH
}

\author{
„Słyszeliśmy nieraz w naszych czasach powiedzenie: \\ «Osoba jest powołaniem». Jest to prawdą pod tym warunkiem, że słowu \\ «powołanie» przywrócimy jego właściwe znaczenie, polegające na rozumieniu \\ go jako wezwania lub, ściślej, jako odpowiedzi na wezwanie" \\ (Gabriel Marcel, Homo viator, 1984).
}

Streszczenie: Artykuł jest próbą przybliżenia rozumienia osoby w ujęciu Gabriela Marcela. Swą refleksję określa on jako filozofię konkretną, w przeciwieństwie do myśli abstrakcyjnej. Zasadniczą daną jest człowiek jako byt wcielony, wcielony w ciało, ale także w konkretną rzeczywistość życia jaką stanowi rodzina, tradycja, w szerszym rozumieniu dziedzictwo duchowe. Konsekwencją takiego widzenia osoby jest wezwanie do tworzenia własnego człowieczeństwa, przechodzenia od chęci posiadania ku pragnieniu bycia, stawania się osobą. Wyciągnięcie wniosków z tej zasadniczej danej niesie ze sobą ważne inspiracje dla pedagogiki i wychowania.

Słowa kluczowe: osoba, wcielenie, filozofia konkretna, być i mieć, problem i tajemnica, byt wcielony, rodzina, tradycja, dziedzictwo duchowe

Filozofia Gabriela Marcela to niewątpliwie jeden z najważniejszych i najciekawszych rozdziałów współczesnej myśli filozoficznej, wciąż jeszcze nie dość odkryty i studiowany. Punktem wyjścia francuskiego filozofa jest człowiek i jego konkretne doświadczenie siebie i świata. Swą refleksję określa jako filozofię konkretną, odnoszącą się do konkretnego człowieka, jego życia i osobistego doświadczenia. W dominującej dzisiaj filozofii ponowoczesnej teoretycy postmodernizmu przyjmują postawy sceptycyzmu i relatywizmu wobec osoby i rzeczywistości ludzkiego życia. Ich zdaniem wyczerpały się tradycyjne koncepcje filozoficzne, nastąpił kryzys kultury modernistycznej i koniec samego człowieka. Postuluje się posthumanizm, perspektywę, w której niczego istotnego nie da się już powiedzieć o człowieku. Zostały poddane w wątpliwość systemy wartości, które do tej pory nadawały sens życiu, wyznaczały kanon piękna, porządkowały świat i relacje międzyludzkie. Konsekwencją postmodernistycznej mentalności jest zagubienie człowieka w dzisiejszym świecie. Doświadcza on rozdarcia pomiędzy tym, kim jest, a tym, do 
czego sprowadza go konsumpcyjny model życia. Ponowoczesna filozofia odrywa go od rzeczywistości i prawdziwego życia w świecie. A zatem rodzą się następujące pytania: kim jest osoba w świetle filozofii Gabriela Marcela? Czym jest kategoria wcielenia w ujęciu francuskiego filozofa? Na czym polega jej znaczenie dla pedagogiki i relacji wychowawczych? Oto istotne kwestie, na które będziemy starali się dać odpowiedź w niniejszym artykule.

\section{Osoba jako b y t w c i e lo n y w centrum metafizyki Marcela}

Gabriel Marcel główną swą myśl formułuje następująco: wcielenie jest zasadniczą daną metafizyki. Osoba istnieje jako byt wcielony. Według niego jest to „sytuacja bytu, który ukazuje się sobie jako związany z ciałem... Sytuacja podstawowa, której, ściśle biorąc, nie można opanować, zahamować, zanalizować. Właściwie nie jest to fakt, lecz dana, poczynając od której fakt staje się możliwy" (Marcel 1965, s. 88; 2001, s. 11). Stwierdzenie to staje się fundamentalną zasadą jego poszukiwań filozoficznych.

Człowiek obecnie jest postrzegany w świecie jako jednostka, czyli część społeczeństwa, przedmiot badań i analiz problemowych. Abstrakcyjne widzenie człowieka, w oderwaniu od rzeczywistości jaka go stanowi wewnętrznie, a zarazem konkretnych uwarunkowań zewnętrznych, jest ograniczone i niewystarczające. Osoba jako byt wcielony przeciwstawia się ujęciu abstrakcyjnemu. Nie ma człowieka „w ogóle”, nie ma wychowanka „w ogóle”, jest natomiast konkretny człowiek włączony w określoną rzeczywistość życia, partycypujący w Bycie Absolutnym, samym Bogu.

Kategoria wcielenia w ujęciu francuskiego filozofa jest pewnym szczególnym sposobem istnienia człowieka w świecie, bycia w nim zakorzenionym. Wcielenie to sytuacja istoty, która zarówno widzi, jak i doświadcza tego, że jest związana z ciałem, i poprzez to ciało uczestniczy w rzeczywistości. W antropologii filozoficznej Marcela ciało człowieka jest podstawowym źródłem komunikacji z rzeczywistością. Osoba nie może kontaktować się ze światem inaczej niż poprzez swoje ciało. Pisząc o ciele, mogę powiedzieć, że „mam ciało”, ale jednocześnie, że „jestem ciałem”. Ciało jest istotnie włączone w moje konkretne bycie, jest czymś, z czym człowiek bezpośrednio się identyfikuje. Nie jest ono człowiekowi dane w sposób jednoznaczny, gdyż łączy go z nim tajemnicza zażyłość. „Jestem moim ciałem - pisze filozof - tylko o tyle, o ile stanowi ono pewnego rodzaju ze swej istoty tajemniczą rzeczywistość i nie sprowadza się do najbardziej skomplikowanych określeń, którymi odznacza się jako przedmiot” (Marcel 1995, s. 127). Więź, jaka łączy mnie z ciałem, od początku naznaczona jest napięciem między „jestem” i „mam”. Oznacza to, że w osobie ze względu na ciało przebiega pewna osobliwa granica między byciem a posiadaniem (Marcel 2001, s. 121). W ten sposób dochodzimy do istotnego rozróżnienia, jakie 
wprowadza Marcel, a mianowicie kategorii: być i mieć. Jest ona ważna ze względu na styk rzeczywistości zewnętrznej i wewnętrznej, jaka dotyczy bezpośrednio osoby i pozostaje dla niej wezwaniem do podjęcia określonego wyboru.

Dojrzewanie człowieka do bycia osobą wiąże się z kluczowym wyborem. Jest to proces, który rozpoczyna się w momencie, gdy człowiek świadomie zapragnie być kimś więcej niż posiadającym tylko własne, egoistyczne upodobanie w swoim „ja”. Ze swej istoty jest „bytem-w-sytuacji”, w określonej rzeczywistości i relacjach międzyludzkich. Sytuacyjność podmiotu jest wezwaniem do podjęcia wyboru i świadomego zaangażowania się w rzeczywistość (Marcel 1965, s. 111). Oznacza to, że konkretne okoliczności życia człowieka mają na niego wpływ i pozostają w głębokim związku z tym, kim jest.

Ciało człowieka staje się miejscem doświadczenia siebie w świecie, wejścia w sytuacje tzw. prób życiowych i zmagania się z nimi. Jednocześnie próby te wpisują się w proces tworzenia własnego człowieczeństwa, a ostatecznie zmierzania do pełni bycia osobowego. Ciało zatem nie może być traktowane jak przedmiot użycia, który jest zewnętrzny w stosunku do mnie. Spełnia ono, jak powie filozof, misję pośrednika pomiędzy mną a rzeczywistością, w której nie tylko egzystuję, ale przede wszystkim wewnętrznie partycypuję. To szczególnego rodzaju uczestnictwo wyraża się w doświadczeniu związanym z podmiotowym czuciem siebie w świecie. Filozof pisze: „W ten sposób zostajemy zmuszeni do wprowadzenia ciała-podmiotu. O ile podtrzymuję z nim pewnego rodzaju relację [...], która nie daje się zobiektywizować, mogę twierdzić, że jestem identyczny z moim ciałem” (Marcel 1995, s. 125). Ciało-podmiot jest więc zapośredniczeniem sympatycznym w stosunku do rzeczywistości (Marcel 1987, s. 192). Określa je mediacją sympatyczną w przeciwieństwie do instrumentalnego traktowania ciała, które nazywa mediacją instrumentalną. To podmiotowe przeżywanie własnej cielesności jako potencjalności ludzkiego istnienia, pewnego wezwania, urzeczywistnia się w coraz głębszym byciu osobą. Człowiek jako byt wcielony stanowi zatem jedność w swym osobowym bycie.

Warto zauważyć, że tę samą ważną intuicję dotyczącą ciała i cielesności człowieka odnajdujemy w teologii ciała i antropologii integralnej św. Jana Pawła II. W dziele Mężczyzną i niewiastą stworzył ich (Jan Paweł II 1982) Wojtyła mówi wprost, że to ciało objawia osobę. Ciało wyraża podmiotowość człowieka, nie tylko jego jaźń, świadomość, rozum, ale właśnie ciało. To stwierdzenie w kontekście filozofii nowożytnej, pokartezjańskiej, wydaje się bardzo ważne, wręcz rewolucyjne.

Człowiek jako byt wcielony jest homo viator, kimś, kto jest w drodze własnego rozwoju. Cel marcelowskiego homo viator jest określony. Jest nim zmierzanie do pełni bycia osobowego i zjednoczenia z Bytem Absolutnym. Jest on wezwany do transcendowania siebie i tworzenia relacji podmiotowych $z$ innymi. Jego życie posiada perspektywę nadprzyrodzoną. Filozof w następujący sposób określa osobę: „pojmuje ona siebie w znacznie większym stopniu jako wolę niż jako byt, jako wolę przewyższania tego wszystkiego, czym jest i zarazem nie jest, jako wolę 
przewyższenia teraźniejszości, w którą czuje się, prawdę mówiąc, zaangażowana czy uwikłana, a która jednak jej nie wystarcza, która nie jest na miarę dążeń, z jakimi osoba się utożsamia. Jej dewizą nie jest sum, ale sursum" (Marcel 1984, s. 25).

\section{Filoz of i a k n r e t n a odpowiedzią na widzenie osoby jako tajemnicy}

Istotne rozróżnienie, jakie wprowadza francuski filozof, jest związane z problemem i tajemnicą. Podmiot Marcela jest tajemnicą niepoddającą się obiektywizacji i bezosobowej analizie. Do tajemnicy się przybliżamy, by ją odkrywać i w niej partycypować. Problem natomiast stwierdzamy, by go analizować i ostatecznie rozwiązać. Zatem kategoria bytu wcielonego stanowi kategorię nie problemu, lecz tajemnicy ontologicznej.

Marcel dokonuje pewnego ważnego przełomu, z którego warto zdać sobie sprawę. Czyniąc byt wcielony punktem wyjścia swej antropologii, przeciwstawia się kartezjańskiemu widzeniu człowieka. W swoim dziele o znaczącym tytule Od sprzeciwu do wezwania pisze: „Prawdę mówiąc, urok, jaki cogito wywarło na filozofów, tkwi właśnie w jego przynajmniej pozornej przejrzystości. Zawsze jednak można postawić pytanie, czy ta przejrzystość nie jest tylko pretensją do przejrzystości. Sądzę, że mamy tu do czynienia z dylematem: albo jest to tylko złudzenie i, jak skłonny jestem przypuszczać, w samej głębi cogito pozostaje jakiś element nieznany, niemożliwy do wyjaśnienia, albo, jeśli cogito jest rzeczywiście przejrzyste dla siebie samego, nigdy i za pomocą żadnego procesu logicznego nie wydobędziemy zeń nic egzystencjalnego" (Marcel 1965, s. 89).

Marcelowska kategoria wcielenia jest opozycją wobec cogito. W miejsce kartezjańskiego cogito, nowożytnego przełomu w myśleniu otwierającego drogę idealizmowi, podkreśla cielesność człowieka związaną z jego istnieniem. Więcej, zwraca uwagę na sum, które zmierza do sursum, do stawania się tym, kim jestem, do zmierzania w swym człowieczeństwie do bycia. W ten sposób sprzeciwia się on systemom filozoficznym pozostającym na zewnątrz opisywanej rzeczywistości i samego człowieka. Według niego rozumienie człowieka w sposób abstrakcyjny wyobcowuje go z rzeczywistości podmiotowego istnienia w świecie i możliwości głębokiego dojrzewania moralno-etycznego.

Główną troską Marcela jest budowanie filozofii integralnego podmiotu, to znaczy konkretnego wcielonego i wolnego „ja”. Jak zauważa Karol Tarnowski, dlatego wchodzi on w polemikę z systemami filozoficznymi i różnymi odmianami europejskiego racjonalizmu oraz poddaje krytyce filozofię idealistyczną związaną z Kantem, Fichtem, Heglem oraz Brunschvicgiem. Racjonalista bowiem ujmuje wszystko przez pryzmat konieczności, systemu, a zatem to, co indywidualne, skończone, jawi mu się jako przypadkowe. Marcel natomiast broni tej nierozerwalnej jedności myślenia i doświadczenia człowieka. Zdaniem Karola Tarnowskiego głównym przedmiotem polemiki nie jest filozofia Kanta, którego i tak krytykuje, lecz idealizm absolutny Hegla oraz scjentyzm w wydaniu Brunschvicga (Tarnowski 
1993, s. 12, 17). W idealizmie bowiem to właśnie myśl jest utożsamiona z całokształtem rzeczywistości i w tym sensie jest bytem absolutnym. Jawi się ona jako najważniejsza prawda i tylko w niej istnieje to, co skończone. Zatem konkretny człowiek jest umieszczony obok skończonych rzeczy. Dla Brunschvicga natomiast jedyną prawdą rzeczywistą jest to, co podlega prawom nauki. Zatem istnieje tylko to, co można sprawdzić (Tarnowski 1993, s. 18).

Próbą przybliżenia się do człowieka i prawdziwego jego widzenia jest marcelowska filozofia konkretna. Czym jest ten rodzaj filozofowania i jakie ma znaczenie dla widzenia i odkrywania osoby? Filozofia konkretna przeciwstawia się filozofii abstrakcyjnej, oderwanej od człowieka i jego życia. Nie można nic istotnego powiedzieć o człowieku przy pomocy pojęć teoretycznych, będąc na zewnątrz niego, pomijając wymiar egzystencjalny i religijno-duchowy. „Wierzę, że bardziej od sztuki czy liryzmu - pisze filozof - w tragicznych zmaganiach współczesnego świata potrzebna jest pewna metafizyka konkretna i jak gdyby uzgodniona $z$ tym, co najintymniejsze w doświadczeniu osobistym, mogąca grać decydującą rolę dla wielu dusz" (Marcel 2001, s. 294).

Charakterystyczną cechą filozofii konkretnej jest zaangażowanie w życie człowieka tu i teraz, odniesienie do osoby ludzkiej jako wartości szczególnego rodzaju. Nie chodzi w niej o konstruowanie nowych teorii, budowanie ponowoczesnych schematów myślowych lub tworzenie abstrakcyjnych hipotez naukowych. Można powiedzieć, że refleksja Marcela jest asystemowa, żywa, metodologicznie nieweryfikowalna, by w ten sposób pozostać otwartą na prawdę o człowieku, na dobro, którym jest. Określa ją refleksją „wtórną” lub inaczej „pogłębioną”, przeciwstawiając ją refleksji „pierwszej”, abstrakcyjnej, zewnętrznej, odnoszącej się do powierzchownego opisu rzeczywistości. Refleksja „pogłębiona”, „druga” natomiast jest tą, która odzyskuje to wszystko, co pominęła czy utraciła wręcz refleksja typu pierwszego. Refleksja „druga”, zwana też „odzyskującą”, przeniknięta jest marcelowskim tzw. niepokojem metafizycznym, czyli niepokojem o człowieka w jego stawaniu się tym, kim jest. Szczególnym miejscem ujawniania się metafizycznego niepokoju jest doświadczenie człowieka. Stąd tak duża troska o to, co człowiek przeżywa i czuje, w jaki sposób doświadcza rzeczywistości, która go otacza. W tym sensie doświadczenia wewnętrzne mają wartość ontologiczną, gdyż pozwalają przybliżyć się do tajemnicy ludzkiego bycia w świecie.

W związku z tym to, co jest ważne dla wychowania, to zdanie sobie sprawy, że dojrzewanie osoby nie przebiega według z góry przyjętego wcześniej schematu i założeń programowych. Osoba wychowanka nie przynależy do kategorii problemu, lecz odnosi się, niejako ciąży ku tajemnicy ontologicznej. Tylko w takiej perspektywie widzenie osoby wychowanka i towarzyszenie mu w drodze dojrzewania ku pełni człowieczeństwa ma sens. Wychowawca to ten, który pomaga wychowankowi odkrywać prawdę o ludzkim istnieniu w świecie i przybliżać się do niej dzięki osobistemu doświadczeniu i dawaniu świadectwa. Jest kimś, kto towarzyszy i jest zaangażowany wychowawczo w to, co uczeń przeżywa, czym żyje. Wskazuje to na 
znaczenie relacji wychowawczych, na rolę, jaką odgrywa marcelowskie napięcie miedzy „być” i „mieć” ludzkiego istnienia. Według Marcela nie ma filozofii konkretnej bez twórczego napięcia pomiędzy „ja” i głębią Bytu, w którym i przez który jesteśmy (Marcel 1965, s. 88). Rolą wychowawcy jest więc pomagać wychowankowi odkrywać równowagę pomiędzy „być” i „mieć”, pomiędzy tym, kim jestem i do czego jestem wezwany, a tym, co mam, posiadam, co składa się na moje zewnętrzne tylko uposażenie. Zatem marcelowski niepokój metafizyczny jest czymś, co drąży, niepokoi ludzkie serce, przypomina człowiekowi, że nie żyje tylko dla siebie, gdyż potrzebuje odniesienia do bliźniego, a ostatecznie do Ty Absolutnego, Boga, który jest pełnią wszystkich ludzkich ograniczeń.

Konkretny wychowanek jest wezwany do przekraczania i odkrywania siebie jako tajemnicy, co oznacza otwieranie się na drugiego człowieka, na jego obecność, która wzywa mnie do zajęcia określonego stanowiska. Dokonuje się to dzięki zaangażowaniu człowieka na rzecz innych ludzi, dzięki postawom wiary, nadziei, miłości oraz wierności twórczej. Postawy te, ze względu na ograniczony zakres niniejszego artykułu, nie będą przez mnie prezentowane. Jednakże warto w tym miejscu podkreślić, że wartość marcelowskich refleksji z nimi związanych jest nieoceniona.

W świetle powyższych analiz należy powiedzieć, że metafizyczny niepokój podważa ludzkie zadowolenie z siebie. Nie pozwala być spokojnym wobec prawdy sumienia, jakby wybudza człowieka z moralnego uśpienia. Marcel pisze: „Lecz to niezadowolenie $z$ siebie nie jest niczym innym jak niepokojem, zauważmy tutaj, jak może stać się on aktywną zasadą dynamizmu duchowego skierowaną ku transcendencji” (Marcel 1955, s. 107). W ten sposób marcelowski niepokój staje się zasadą dojrzewania moralnego wychowanka. Jego owocem jest osobisty wysiłek rozumienia siebie i innych dzięki przybliżaniu się do tajemnicy własnego bytu.

\section{W c i e l e n i e jako konkretna rzeczywistość życia człowieka}

Kategoria wcielenia w rozumieniu Gabriela Marcela utożsamia się z konkretną rzeczywistością ludzkiego życia. Wcielenie obejmuje zatem: rodzinę, w której przyszliśmy na świat, społeczność lokalną, sąsiedztwo, szkołę, do której uczęszczaliśmy, następnie środowisko pracy, klimat miasta wraz z jego kulturą i historią. Miejsca te wiążą się z naszymi wspomnieniami, których wartość i znaczenie zazwyczaj doceniamy po latach. Tę „wcieloną” niejako w człowieka i z nim ucieleśnioną rzeczywistość stanowi zatem: rodzina, szkoła, społeczność, Kościół, naród. W rozumieniu Marcela podmiot wcielony jest związany z określoną tradycją i kulturą, historią ojczystą i ludźmi ją tworzącymi. Tak rozumiane wcielenie w sposób zasadniczy ujawnia ważność ludzkiego bycia oraz życia w uporządkowanym świecie. W tym świecie szczególne miejsce zajmuje rodzina. Na konferencji wygłoszonej w École des Hautes Études Familiales w Lyonie i Tuluzie w roku 1942 Marcel zwracał uwagę na znaczenie rodziny w życiu człowieka (1984). Zwłaszcza dzisiaj, gdy jest tak bardzo 
dyskredytowana w życiu państwowym i społeczno-kulturowym, istotny jest powrót do jej niezaprzeczalnej roli, jaką odgrywa w dojrzewaniu młodego człowieka i budowaniu międzyludzkich relacji.

\section{Rodzina i tradycja zakorzenieniem człowieka}

Istnieje uzasadniona konieczność mówienia i pisania na temat znaczenia rodziny w życiu i wychowaniu człowieka. Marcel pisze o potrzebie wejrzenia w tajemnicę rodziny, by na nowo przywrócić duszę tej szczególnej rzeczywistości, jaką jest (Marcel 1984, s. 75). Odnosi się wrażenie, że w dzisiejszej kulturze zatracony został sens istnienia rodziny jako podstawowego środowiska życia i rozwoju dziecka. Próby zastąpienia pojęć ojca i matki pojęciami takim jak „rodzic jeden” i „rodzic dwa" wprowadzają fałsz w rzeczywistość ludzkiego życia. Spotykamy się ze wzmożonym atakiem na rodzinę ze strony ideologii gender i środowisk jej przychylnych. Jedną z istotnych form takiego postępowania stanowi proces legislacyjny, poprzez który wprowadza się w państwie ustawy naruszające dotychczasowy porządek bez prowadzenia na szeroką skalę konstruktywnych debat społecznych. Marcel zwraca uwagę na kryzys powagi rodziny i życia społecznego jako takiego. Ten związek rodziny i życia w podstawowym i pierwotnym rozumieniu, ich witalnych korzeni, ulega rozerwaniu. Powaga życia, jego sens i znaczenie zostały zastąpione banalizacją życia społecznego, neoliberalnym dyskursem, którego konsekwencją jest powierzchowna analiza rzeczywistości, bez odniesienia do wartości.

Osoba ludzka, czy to uznajemy, czy nie, rodzi się w konkretnej, a nie w abstrakcyjnej, bliżej nieokreślonej, kulturowo wykreowanej rodzinie. Rodzina jest wartością niezwykle istotną dla rozwoju człowieka. Niezależnie od dysfunkcji, jakie mogą w niej wystąpić, faktem jest jej fundamentalne znaczenie i rola, jaką odgrywa. Marcel pisze: „gdy mówię o mojej rodzinie, mam początkowo na myśli pewien układ, pewną konstelację, w której w okresie dzieciństwa spontanicznie siebie uważałem za centrum. [...] Równocześnie jednak zmienia się dziwnie rzeźba mojego życia osobistego [...]. Rodzina moja oddala się ode mnie, pozostając jednak tak samo blisko, pozostając jak najbardziej mną samym" (Marcel 1984, s. 73).

Człowiek jako byt wcielony w sposób naturalny odnosi się do konkretnej rodziny jako pewnej wartości. Filozof ukazuje to na przykładzie dumy, jaką odczuwa się z przynależności do określonej wspólnoty osób. Duma jest odpowiedzią wypływającą z głębi mnie samego na nadaną mi godność. Odczuwam ją jako coś wyłącznie osobistego. Składają się na nią nie tylko uznanie hierarchii i autorytetu, który reprezentuje głowa rodziny. Przede wszystkim jest miejscem, w które od początku jestem włączony, do którego przynależę. W rodzinę jestem zakorzeniony całą swoją istotą, jestem w nią zaangażowany osobiście (Marcel 1984, s. 80). W tym przypadku rodzina jawi się jako pewna „powłoka ochronna” rozciągająca się między znanym środowiskiem a nieznanym, obcym światem. „To, co chętnie nazwałbym puszystym elementem ochronnym rzeczywistości rodzinnej, najlepiej oddają zbliżone, 
a niestety strywializowane przez głupio sentymentalną czy dydaktyczną poezję obrazy kokonu, gniazda czy kołyski” (Marcel 1984, s. 80). Obrazowe porównania życia w rodzinie do gniazda i kołyski wskazują na podstawową rolę, jaką odgrywa ona w rozwoju i wychowaniu człowieka.

Rzeczywistość rodziny nieodłącznie wiąże się z wyrażeniem „my” czy „u nas w domu”. Dom jako budowla architektoniczna mająca określone pomieszczenia nie jest tylko zwykłym domem. W przeciwieństwie do mieszkania jest miejscem obecności wspólnoty osób, jaką tworzy rodzina. Mieszkanie staje się domem dzięki obecności osób i historii, dzięki przodkom powiązanym ze sobą więzami krwi i tradycji rodzinnej. Marcel zwraca uwage na szczególnego rodzaju obecność, doświadczenie, jakie wiąże się ze wspomnieniami z dzieciństwa. Świat rzeczy odnosi się do świata osób, które z nich korzystają. Zatem rzeczy, co do których mamy sentymentalne wspomnienia, określone miejsca, w których przebywaliśmy w dzieciństwie, pozostawiają w nas niezatarty ślad swojej obecności. Obecność, w rozumieniu Marcela przejawiająca się w pewnego rodzaju duchowej atmosferze, jest wyrazem trwania przeszłości (Marcel 1984, s. 49). Pozostaje gdzieś na zawsze jakaś żywa więź, która łączy człowieka z otoczeniem, w którym przebywał i które go tworzyło. Francuski filozof pisze o tym w przejmujący sposób: „Spontaniczna i bezpośrednia świadomość jakiegoś zawsze, jakiegoś przeżycia odwieczności wiążącego się z dobrze znanymi przedmiotami, wśród których żyjemy, z otoczeniem, wśród którego wypełnia się codzienne obowiązki, a także z trudnym do sformułowania odczuciem jakiejś opiekuńczej obecności wcielającej się w te przedmioty, w to otoczenie" (Marcel 1984, s. 81). Dlatego zrozumiałe jest rozdarcie czy kryzys, jakie przeżywa dziecko, kiedy doświadcza przeprowadzki w nowe, nieznane miejsce. Zmiana miejsca zamieszkania, opuszczenie rodzinnego domu, tak zwana globalizacja kulturowa osłabia to, co Marcel określa mianem zmysłu rodzinnego. Można powiedzieć, że powoduje wyrwanie człowieka ze świata mu bliskiego i bezpiecznego, i osadzenie go w tym, co niewiadome, wykorzenione z pierwotnego odniesienia do życia w uporządkowanej, wcielonej w nas niejako rzeczywistości.

Gabriel Marcel zwraca uwagę, że z określonym ogniskiem domowym i historią związana jest tradycja rodzinna i narodowa. „Moja rodzina, a raczej moi przodkowie są następstwem okoliczności historycznych, zgodnie z którymi duch ludzki indywidualizował się, by dojść do tego szczególnego bytu, jakim jestem. [...] Między mymi przodkami a mną istnieć musi jakiś nieskończenie mniej jasny i głębszy stosunek: uczestniczymy wzajemnie w niewidzialnym - ja w nich, a oni we mnie; jesteśmy sobie współistotni” (Marcel 1984, s. 74). Zanikanie stałych siedzib, nieustanne migracje członków rodzin związane z poszukiwaniem pracy i lepszych warunków życia są również powodem zanikania tradycji rodzinnych. Marcel diagnozuje to w następujących słowach: „Tradycje są tym dla duszy człowieka, czym bliskie otoczenia dla jego ciała. Nie można powiedzieć, że one go jedynie 
otaczają, one bowiem współdziałają w jego stwarzaniu. Bez nich człowiek może stać się igraszką wpływów" (Marcel 1984, s. 82).

Środowisko rodzinne jest niezastąpionym miejscem odkrywania ważności własnego istnienia w świecie, więzi ze wszystkim, co mnie otacza. A zatem więź łącząca mnie z moim ciałem i więź duchowa, łącząca mnie ze światem rzeczy materialnych, nie są przypadkowe. Wszystko to, co pozostawia we mnie żywą obecność, nadal żyje we mnie, jest częścią mnie. „Między tajemnicą zjednoczenia duszy i ciała a tajemnicą rodziny istnieje głęboka jedność, którą prawdopodobnie za mało się podkreśla: i tu, i tam stajemy wobec tego samego faktu, a raczej wobec czegoś, co jest czymś więcej niż faktem, bo warunkiem wszelkich faktów - wcieleniem" (Marcel 1984, s. 72).

Wcielenie jako „wkorzenienie” w dziedzictwo duchowe

Z pojęciem podmiotu w marcelowskim rozumieniu wiąże się pojęcie dziedzictwa. Osoba jako byt wcielony w konkretny sposób odniesiona jest do dziedzictwa historycznego i kulturowego, które Marcel określa dziedzictwem duchowym. Filozof stwierdza: „coraz większa liczba istot ludzkich nie rozpoznaje już dziedzictwa duchowego jako takiego, a ściślej odmawia jego przyjęcia, jak odmawia się przyjęcia spadku nakładającego na beneficjenta kosztowne zobowiązania" (Marcel 2011, s. 42-43). Jego zdaniem nastąpiła zmiana perspektywy widzenia rzeczywistości historycznej. Zamiast otwarcia się na pozostawione nam przez naszych przodków dziedzictwo jesteśmy świadkami postawy niechęci, wręcz sprzeniewierzania się jemu i tym, którzy je tworzyli. Pojawia się moda na ośmieszanie historii, dyskredytowanie autorytetów, umniejszanie zasług bohaterów narodowych. Mówienie o patriotyzmie i publiczne przyznawanie się do niego budzą niechęć i dezaprobatę, powodują to tzw. poprawność polityczna i tolerancja. W programach szkolnych liczba godzin historii ulega zmniejszeniu na rzecz tzw. przedmiotów praktycznych, bardziej użytecznych we współczesnym świecie. Nastąpił rozdźwięk między nauczaniem a wychowaniem młodego człowieka. Szkoła edukuje, ale nie wychowuje do postawy szacunku wobec dziedzictwa narodowego. W miejsce pytania o etyczne wychowanie w szkole pojawia się pytanie o efektywne działania szkoły i jej sukcesy edukacyjne.

Zdaniem Marcela tym, co sprawia, że dziedzictwo duchowe jest żywe i trwałe, jest świadomość jego znaczenia. Świadomość wartości dziedzictwa duchowego wyraża się w postawie wdzięczności. W dzisiejszym świecie jesteśmy świadkami zaniku tej postawy w życiu społecznym. Zdolność do wdzięczności wobec ludzi, którzy tworzyli historię i budowali określone dziedzictwo, związana jest ze zdolnością do okazywania podziwu (Marcel 2011, s. 46). W rozumieniu Marcela wdzięczność jest szczególną postawą osoby świadomej siebie, dojrzałej do właściwego odniesienia się do przeszłości. Wdzięczność ma charakter trwały, jej podstawę stanowi pamięć, która nie polega jedynie na zapamiętywaniu. Należy ją rozumieć 
jako czujność osoby, pewien „stan duszy czuwającej nad tym, by nie utracić tego, co przedstawia dla niej trwałą wartość”. Osoba przejawia zdolność do czujności, stanowiącej „aktywną walkę z siłami wewnętrznego rozproszenia, powiedzmy nawet roztargnienia” (Marcel 2011, s. 48).

Przeszłość i ciągłość historyczna danego narodu pozostawiają niezatarte piętno na człowieku i jego tożsamości osobowej. Jego dojrzałość będzie wyrażała się w trosce o tę pamięć i w szacunku wobec dziedzictwa duchowego, w które jest wcielony. Przeciwieństwem pamięci i wdzięczności jest pretensjonalność, skupienie na sobie, postawa wydziedziczenia. Egocentryzm i indywidualizm życia stają się przejawem źle rozumianej wolności. Konsekwencją braku odniesienia do wartości, jakie niesie ze sobą dziedzictwo duchowe narodu, jest zubożenie samego człowieka oraz życia rodzinnego i społecznego. Człowiek przestaje rozumieć samego siebie i innych ludzi, którzy żyją obok niego. Staje się jakby duchowo bezdomny, zagubiony w świecie, samotny. W pedagogii Gabriela Marcela to właśnie wierność człowieka samemu sobie wiąże się z wiernością dziedzictwu duchowemu. Przeciwstawia się ona temu, by więcej „mieć” niż „być”, czyli konsumpcjonizmowi życia. W rozumieniu filozofa chodzi o masowe podejście do życia pozbawione pierwotnego widzenia go jako sacrum i osoby jako podmiotu obdarzonego darem życia. Globalizacja życia gospodarczego nie pozostaje bez wpływu na ujednolicanie życia społeczno-kulturowego poszczególnych państw Europy. Wynikiem takiego działania jest utrata żywotności i duchowej tożsamości poszczególnych narodów. Człowiek staje się mieszkańcem anonimowej aglomeracji pozbawionej swoich korzeni, przestaje być zakorzeniony w tym, co rodzime, narodowe, we własnym dziedzictwie kulturowym.

Marcel zauważa, że dziedzictwo duchowe przedstawia się jako pośrednictwo między osobą a światem ducha, rzeczywistością nadprzyrodzoną. Może ono zostać rozpoznane tylko „w świetle Idei ducha”. Im bardziej owa idea zanika w ludzkiej świadomości, tym bardziej ulega zatraceniu samo pojęcie dziedzictwa. Zacieranie się idei dziedzictwa duchowego znajduje swój wyraz w postępującej bezbożności, braku sakralnego widzenia świata (Marcel 2011, s. 54). Skutkiem takiego postępowania staje się relatywizacja życia społecznego i jego sekularyzacja. To, co było nienaruszalne, otoczone poczuciem sacrum, w dzisiejszym świecie staje się zdesakralizowane, pozbawione podmiotowego odniesienia do człowieka.

Francuski filozof dochodzi do wniosku, że pojęcie duchowego dziedzictwa, tak ważne dla rozumienia człowieka przez właściwe odniesienie do osoby, jak również rozumienie osoby przez nią samą, uniemożliwione jest przez utratę własnego odniesienia do historii i tradycji. Historia traci swoje znaczenie, mówiąc językiem Marcela „swoją żywotność”, w wyniku gromadzenia jedynie dokumentów. Filozof wskazuje na istotne znaczenie, jakie odgrywa przypominanie historii, pamięć o przeszłości (Marcel 2011, s. 55). Nie można poprzestać jedynie na zbieraniu dokumentów, ważne jest przede wszystkim przekazywanie pamięci, dawanie świadectwa wobec innych o jej wartości dla bycia osobowego. Postrzeganie siebie jako spadkobiercy, jako kogoś wezwanego do przekazywania dziedzictwa jest wyzwaniem dla 
wychowania dzisiaj. Rozpoznanie to pokrywa się z odkrywaniem i przybliżaniem się do własnego bytu. Francuski filozof pisze: „linia tego rozpoznania pokrywa się $\mathrm{z}$ linią mojego bytu, niebędącego daną raz na zawsze naturą, lecz twórczym dążeniem - po raz kolejny odnajdujemy tu niewyczerpaną w swym znaczeniu formułę: stań się tym, kim jesteś" (Marcel 2011, s. 57). W tym właśnie sensie, w rozumieniu Marcela, osoba jest powołaniem.

\section{Inspiracje wychowawcze pedagogii Gabriela Marcela}

Pedagogia osoby w ujęciu Gabriela Marcela, w moim przekonaniu, wiąże się $\mathrm{z}$ wieloma cennymi wnioskami, istotnymi dla pedagogiki i relacji wychowawczych. Wymieńmy te najważniejsze, które zostały podjęte w artykule w sposób mimo wszystko ograniczony ze względu na możliwości niniejszej publikacji. Wychowankowi uwikłanemu w narastającą chęć posiadania, tego, by więcej mieć, została zaproponowana rzeczywistość wychowania jako droga odkrywania tajemnicy własnego bycia w rozumieniu francuskiego filozofa.

Osoba jako byt wcielony jest tajemnicą. Tajemnica jest tym, co „metaproblematyczne", transcendentne, niepoddające się problematyzacji. Problematyzowanie bowiem pociąga za sobą abstrakcyjne odniesienie do życia, zerwanie tej pierwotnej więzi, która wewnętrznie spaja podmiot z rzeczywistością (Marcel 2001, s. 145-146). Obecnie widzimy niepokojące tendencje związane z funkcjonalnym i użytecznym podejściem do człowieka i świata. Podobne mechanizmy oddziaływań edukacyjnych, tzw. nadzoru pedagogicznego, dostrzegamy w placówkach szkolnych. Przejawia się to w nadmiernej biurokratyzacji życia społecznego, pragmatycznym nastawieniu do rzeczywistości, poszukiwaniu efektywnych oddziaływań w szkole. Konsekwencją problematycznego widzenia człowiek jest praktyka kontrolowania go przez wzrastającą liczbę przepisów prawnych, zarówno w życiu społecznym, jak i szkolnym. Relacje międzyludzkie zostały zastąpione urzędowymi, bezosobowymi przepisami. Stąd tak ważne jest marcelowskie rozumienie osoby jako tajemnicy, by przywrócić właściwy kierunek refleksji pedagogicznej i zwrócić na nowo uwagę na znaczenie relacji podmiotowych w szkole. Istotne zatem jest przywrócenie szkole jej podmiotowości, wyrażającej się w samodzielności inicjatyw i twórczym, wartościującym wychowaniu uczniów. Podmiotowość szkoły wyraża się w rozumieniu jej jako wspólnoty tworzących ją osób: uczniów, nauczycieli-wychowawców, rodziców oraz pozostałych zatrudnionych w niej pracowników. Właściwe odniesienie wobec wychowanka i rozumienie szkoły jako wspólnoty szanujących się osób są ważne ze względu na misję wychowawczą, jaką szkoła powinna pełnić. Zwłaszcza dzisiaj, kiedy masowa edukacja zagraża jej podmiotowej egzystencji, a tym samym wychowawczej roli, mówienie o jej zasadniczej misji jest konieczne.

Marcelowskie widzenie osoby jako tajemnicy wiąże się z konkretnym wymiarem relacji wychowawca - wychowanek, jakim jest towarzyszenie. Wychowawca jest kimś, kto towarzyszy, jest zaangażowany wychowawczo, pomaga wychowankowi 
zobaczyć to wszystko, co jest ważne dla jego rozwoju osobowego i relacji międzyludzkich. W pedagogii Gabriela Marcela chodzi o zasadniczy wybór wychowanka, o chęć przekształcania posiadania, tego, by mieć, w pragnienie bycia, bycia osobą. Wychowanie jest więc procesem związanym $\mathrm{z}$ wysiłkiem rezygnacji $\mathrm{z}$ własnego egoizmu i indywidualizmu na rzecz budowania wspólnoty z innymi ludźmi. Owocem tego procesu jest dojrzewanie do bycia dla drugiego człowieka. „Najlepsza cząstka mnie samego - pisze Marcel - nie należy do mnie, nie jestem jej właścicielem, a jedynie depozytariuszem" (Marcel 1984, s. 18).

Zaproponowane w niniejszym artykule rozumienie człowieka jako tajemnicy, jako bytu wcielonego, dynamicznego w swych potencjalnych możliwościach istnienia jest wyzwaniem dla wychowania i pedagogiki dzisiaj. W wychowaniu nie można pomijać „wcielenia” jako zakorzenienia człowieka w konkretną rzeczywistość jego życia. Nie można pomijać korzeni człowieka, czyli wspólnoty osób, jaką jest - w pierwszym rzędzie - rodzina. W szerszym znaczeniu wcielenie dotyczy więzi, jakie tworzy się we wspólnocie lokalnej, społecznej aż po narodową i cywilizacyjną włącznie.

Osoba w ujęciu Gabriela Marcela jest powołaniem. Oznacza to, że od podstawowego pytania: „kim jestem?”, ważniejsze jest pytanie o bycie, o to „kim chcę być?” i „do czego jestem powołany, czyli wezwany?”. Pytanie to jest skierowane w pierwszym rzędzie do mnie samego, filozof zapytuje bowiem: „kim jestem ja, który pytam o bycie?” (Marcel 2001, s. 161). Ostatecznie jednak to moje bycie pozostaje wciąż tajemnicą. Przybliżam się do siebie dzięki tworzeniu relacji z drugim człowiekiem, który objawia mi coraz bardziej samego siebie. W ten sposób urzeczywistniam siebie i aktualizuję złożone we mnie możliwości istnienia osobowego bycia depozytariuszem. Zatem wezwanie to jest powołaniem do dania pozytywnej, afirmującej, odpowiedzi ze strony samego człowieka na dar drugiej osoby.

Oryginalność myśli francuskiego filozofa wyraża się w jego ontyczno-religijnej wizji człowieka, naznaczonej głęboko chrześcijańską perspektywą widzenia osoby. Człowiek jako bycie wcielone zmierza ku pełni Bycia związanego z życiem nadprzyrodzonym. W wychowaniu zatem nie można pomijać konkretnej egzystencji człowieka, w tym jego cielesności, jak również wymiaru duchowo-religijnego. Oba te wymiary ludzkiego życia są fundamentalne dla twórczego i w pełni osobowego rozwoju wychowanka. „Chcę przez to po prostu powiedzieć - pisze filozof - że osoba realizuje się wyłącznie w akcie, poprzez który dąży ona do wcielania się (czy to w dzieło, czy w jakieś działanie, czy w życie jako całość), ale jednocześnie do istoty tego aktu należy, że nigdy nie może on zakrzepnąć. [...] Dlaczego? Dlatego, że osoba uczestniczy w niewyczerpalnej pełni bytu, z którego sama się wyłania. W tym tkwi głęboka przyczyna, dla której nie można pojąć osoby ani porządku osobowego w oderwaniu od tego, co jest poza nią i poza nim - w oderwaniu od rzeczywistości ponadosobowej, która kieruje wszystkimi jej poczynaniami i jest zarazem jej początkiem i jej końcem" (Marcel 1984, s. 26). 


\section{Podsumowanie}

Perspektywa marcelowskiego ujęcia osoby jako bytu wcielonego czyni z francuskiego filozofa promotora metafizyki wcielenia. W ujęciu Gabriela Marcela rozumieć człowieka to widzieć go i odkrywać w łączności z rzeczywistością, jaka go otacza. W wychowaniu zatem będzie chodziło o widzenie wychowanka w całej złożoności tych uwarunkowań, które wiążą się z jego życiem i doświadczeniem. Wychowanek żyje w konkretnej rzeczywistości, to znaczy: rodzinie, środowisku, szkole, kulturze, narodzie, cywilizacji. Wychowawca zatem powinien odczytywać te wzajemnie przenikające się rzeczywistości ludzkiego istnienia - egzystencjalną i religijno-duchową - by pomagać wychowankowi w odkrywaniu prawdy o ludzkim istnieniu w świecie. Odczytywanie tej prawdy i dawanie o niej świadectwa wiąże się ściśle $\mathrm{z}$ sensem i celem wychowania. Wciąż potrzeba nam powrotu marcelowskiej refleksji „drugiej”, „pogłębionej”, do tego, co fundamentalne, konkretne dla człowieka i jego podmiotowego życia w świecie. Jednocześnie bowiem ten cielesny człowiek przekracza swoje ciało, jest istotą duchową zdolną do transcendowania, czyli tworzenia siebie. Jak zauważa Andrzej Gielarowski, refleksje nad cielesnością, jakich dokonuje Gabriel Marcel w swych dziełach, są wciąż aktualne i pozwalają zaliczyć go do najbardziej twórczych filozofów XX wieku (Gielarowski 2013, s. 71). Zaangażowanie wychowawcy, podmiotowe widzenie ucznia, wartościujące odniesienie do rzeczywistości oraz twórcze towarzyszenie wychowankowi w jego drodze do pełni bycia osobowego są ważne dla wychowania i pedagogiki dzisiaj.

\section{Bibliografia}

Gielarowski A. (2013). Tajemnica obecności. Bycie i intersubiektywność w filozofii Gabriela Marcela. Kraków: Akademia Ignatianum i Wydawnictwo WAM.

Jan Paweł II (1982). Mężczyzna i niewiasta stworzył ich. Lublin: Redakcja Wydawnictw Katolickiego Uniwersytetu Lubelskiego.

Marcel G. (2001). Być i mieć, tłum. Eska D. Warszawa: De Agostini i Instytut Wydawniczy PAX.

Marcel G. (1987). Dziennik metafizyczny, tłum. Wende E. Warszawa: Instytut Wydawniczy PAX.

Marcel G. (1984). Homo viator. Wstęp do metafizyki nadziei, tłum. Lubicz P., posł. Podsiad A. Warszawa: Instytut Wydawniczy PAX.

Marcel G. (1955). L' homme problématique, Paris: Aubier, Édition Montaigne.

Marcel G. (2011). Mądrość i poczucie sacrum, tłum. Chodacki K., Chołda P. Kraków: Wydawnictwo Arcana.

Marcel G. (1965). Od sprzeciwu do wezwania, tłum. Ławicki S. Warszawa: Instytut Wydawniczy PAX.

Marcel G. (1995). Tajemnica bytu, tłum. Frankiewicz M., przed. Tarnowski K. Kraków: Wydawnictwo Znak. 
Marcel G. (1984). Tajemnica rodziny. W: Marcel G., Homo viator. Wstęp do metafizyki nadziei. Warszawa: Instytut Wydawniczy PAX, s. 71-99.

Tarnowski K. (1993). Ku absolutnej ucieczce. Bóg i wiara w filozofii Gabriela Marcela. Kraków: Wydawnictwo Naukowe Papieskiej Akademii Teologicznej.

\title{
THE NOTION OF A PERSON IN GABRIEL MARCEL'S SPIN AS THE SOURCE OF EDUCATIONAL INSPIRATION
}

\begin{abstract}
The article is an attempt to understand what Gabriel Marcel means by a notion of the person. He defines his ideas as concrete philosophy opposed to abstract philosophical thought. His core idea is a human as an incarnated being, who received the flesh body but was also integrated into a certain reality such as a family, tradition, and broadly perceived spiritual heritage. The implication of his philosophy is an appeal to create our own personal humanity by progressing from the desire to possess towards the desire to be and to become the person. Drawing the right conclusions from Marcel's philosophy brings on significant inspirations for modern pedagogics and education.
\end{abstract}

Key words: the person, incarnation, concrete philosophy, to be and to possess, a problem and a mystery, incarnated being, family, tradition, spiritual heritage

Jolanta Konkowska - magister historii UW, magister teologii PWTW, doktor nauk humanistycznych w zakresie pedagogiki KUL. Przedmiot rozprawy: Wychowanie jako droga odkrywania tajemnicy istnienia w ujęciu Gabriela Marcela. Nauczyciel szkół warszawskich: XXVII LO im. T. Czackiego, Gimnazjum i Liceum Ogólnokształcącego im. N. Żmichowskiej oraz LXVII LO im. J. Nowaka-Jeziorańskiego. Adres e-mail: jola.konkowska@gmail.com. 